\title{
THE MECHANISM OF ANTIMICROBIAL PEPTIDE MPX AGAINST ENTEROHEMORRHAGIC ESCHERICHIA COLI IN VITRO
}

\author{
Xueqin Zhao \\ Postgraduate student \\ Sumy National Agrarian University of Ukraine (Sumy, Ukraine) \\ College of Animal Science and Veterinary Medicine, Henan Institute of Science and Technology (Xinxiang, China) \\ ORCID: 0000-0002-4713-4685, \\ zxueqin0708@163.com

ORCID: 0000-0002-4713-4685,
zxueqin0708@163.com
Hanna Fotina
Doctor of Veterinary Sciences, Professor
Sumy National Agrarian University (Sumy, Ukraine)
ORCID: 0000-0002-0761-3681
hanna.fotina@snau.edu.ua \\ Lei Wang \\ College of Animal Science and Veterinary Medicine, Henan Institute of Science and Technology (Xinxiang, China) \\ ORCID: 0000-0001-7972-7680 \\ wlei_007@163.com
}

Escherichia coli is a facultative anaerobic bacteria that exists in the gastrointestinal tract of humans and animals. It can cause diarrhea, enteritis, destruction of the host's intestinal barrier, and intestinal microecological disturbances. In recent years, due to the abuse of traditional antibiotics, a variety of drug-resistant strains and super bacteria have emerged in an endless stream. Therefore, there is an urgent need to find new alternatives to antibiotics. Antimicrobial peptides are a type of small peptides produced when organisms resist the invasion of foreign microorganisms. They are considered to be the best alternative to antibiotics which has become a research hotspot in recent years. The antimicrobial peptide MPX is extracted from wasp venom and has a good bactericidal effect on many bacteria. To explore the effect of MPX against $E$. coli. The function of MPX against $E$. coli was detected by MIC, plate count, propidium iodide, NPN and DiSC3(5) permeability testing, immunofluorescence microscope observation, and the impact of MPX stability by temperature, $\mathrm{pH}$, ion. In this study, the results found that MPX has good antibacterial activity against $E$. coli, and the minimum inhibitory concentration (MIC) was $31.25 \mathrm{ug} / \mathrm{mL}$. MPX bactericidal kinetics study found that MPX had good bactericidal activity within 6 hours. Bacterial permeability studies have shown that MPX could increase the permeability of bacteria, leading to an increase in the protein content of the bacterial supernatant. In addition, NPN, PI and DiSC3(5) results showed that the fluorescence value was positively correlated with MPX. The stability test of MPX found that salt ions, temperature, $\mathrm{pH}$, etc. have a slight influence on its effect. In addition, scanning electron microscopy results showed that the bacteria became smaller and the contents leaked after the action of MPX. The above results showed that MPX has a good bactericidal activity in vitro, laying the foundation for the development of new drugs for the treatment of bacterial infections.

Key words: antimicrobial peptide MPX; Enterohemorrhagic Escherichia coli; in vitro

DOI: https://doi.org/10.32845/bsnau.vet.2021.1.3

Introduction. Escherichia coli is a facultative anaerobic bacteria that mainly exists in the gastrointestinal tract of humans and animals, colonize in the small intestine, which is usually associated with acute secretory diarrhea (Fleckenstein J.M. et al., 2010) It can cause diarrhea, enteritis, destruction of the host's intestinal barrier, and intestinal microecological disturbances (Madhavan T.P. et al., 2015). Enterotoxigenic Escherichia coli (ETEC) is classically associated with acute secretory diarrhea, which induces 2 million people death in developing countries over a year, predominantly children in the first years of life (Song $X$. et al., 2021) In addition, in recent years, due to a large number of unreasonable use of antibiotics, the resistance of $E$. coli has increased. The antibiotics, tetracyclines, sulfonamides and penicillins, which are most commonly used in animal production, have the highest resistance rates (Van Boeckel T.P. et al., 2019). Therefore, there is an urgent need to find alternative antibacterial drugs that can treat $E$. coli infections.

Antimicrobial peptides are a class of small defensive peptides produced when organisms resist the invasion of foreign microorganisms. They are an important part of the body's innate immune system (Andrejko M. et al., 2021). Compared with traditional antibiotics, antimicrobial peptides have the characteristics of small molecular weight, good water solubility, good thermal stability, unique antibacterial mechanism, broad-spectrum antibacterial activity against clinically resistant strains, and resistance to bacterial resistance (Luu T. et al., 2021). MPX (H-INWKGIAAMAKKLL-NH2) belongs to the family of bee venom antimicrobial peptides. It has a high content in bee venom. It is an amino acid peptide with 4 net positive charges (Henriksen J.R. et al., 2014). Previous research of our group found that MPX has good antibacterial activity against Actinobacillus pleuropneumoniae. However, it is currently unknown whether MPX has good anti-E. coli activity.

Aim. The aim of this was to study the mechanism of antimicrobial peptide MPX against $E$. coli in vitro. 


\section{Materials and Methods.}

Peptide synthesis.

MPX (H-INWKGIAAMAKKLL-NH2) was obtained by Shanghai Jier Biochemical Company (China) using solid-phase N-9-fluoromethoxycarbonyl (Fmoc) strategy and high performance liquid chromatography (HPLC) purification, and its purity was as high as $98 \%$.

Bactericidal activity test.

E. coli was cultured in LB liquid medium to the logarithmic phase $\left(\mathrm{OD}_{600}=1.0\right)$, and the final concentrations of MPX $(31.25$ $\mathrm{ug} / \mathrm{mL})$, PR39 (50 ug/mL), and Enro (50 ug/mL) were added to the bacterial solution, added $\mathrm{ddH}_{2} \mathrm{O}$ as the negative control, incubated at $37^{\circ} \mathrm{C}$ for $0 \mathrm{~h}, 1 \mathrm{~h}, 2 \mathrm{~h}, 3 \mathrm{~h}, 4 \mathrm{~h}, 5 \mathrm{~h}, 6 \mathrm{~h}$, then measured the $\mathrm{OD}_{600}$ of the bacterial solution and dilute the bacterial solution every $1 \mathrm{~h}$. Put it on the LB plate and incubated in a $37^{\circ} \mathrm{C}$ degree incubator, and incubate for $12 \mathrm{~h}$ until a single colony is clearly visible, and then counted the plates (Wang L. et al., 2017).

The effect of MPX on the outer membrane of $E$. coli.

E. coli were washed with 1:1 mixture of $5 \mathrm{mM}$ HEPES buffer and resuspended with the same. The concentration of E. coli were $1 \times 10^{8} \mathrm{CFU} / \mathrm{mL}$. This study was performed in a Corning 96 black well plate with clear bottom containing $10 \mu \mathrm{M}$ of $\mathrm{N}$ Phenyl naphthylamine (NPN) dye and $190 \mu \mathrm{L}$ of bacterial suspension. After that, bacterial suspensions with dye in each well were treated with $10 \mu \mathrm{L}$ of MPX at concentrations of $1 \mathrm{MIC}, 2$ MIC, 4 MIC. Then, the fluorescence was monitored at an excitation wavelength of $350 \mathrm{~nm}$ and an emission wavelength of 420 $\mathrm{nm}$. The increase in fluorescence intensity was monitored for another 10 min with an INFINITE M PLEX microplate reader (Uppu D.S. et al., 2013).

The effect of MPX on cell plasma membrane.

E. coli were collected separately washed with 1:1 ratio of $5 \mathrm{mM}$ glucose and HEPES buffer $(\mathrm{pH}=7.4)$. Next, the bacterial plate was resuspended in 1:1:1 ratio of 5 mM HEPES buffer, 100 $\mathrm{mM} \mathrm{KCl}$ solution supplemented with $0.2 \mathrm{mM}$ EDTA and $5 \mathrm{mM}$ glucose. For this study EDTA was used to allow the dye uptake by permeabilizing outer membrane of $E$. coli. This study was performed in a Corning 96 black well plate with clear bottom containing $2 \mu \mathrm{M}$ of 3,3'- dipropylthiadicarbocyanine iodide [DiSC3(5)] and $190 \mu \mathrm{L}$ of bacterial suspension. After that, $10 \mu \mathrm{L}$ of MPX (1 MIC, 2 MIC, 4 MIC) was mixed with the suspension of bacteria and dye of each well. In this experiment, $\mathrm{ddH}_{2} \mathrm{O}$ was used as the control. Fluorescence intensity was measured at $622 \mathrm{~nm}$ excitation wavelength and $670 \mathrm{~nm}$ emission wavelength for 10 min using an INFINITE M PLEX microplate reader (Konai M.M. et al., 2014).

The effect of MPX on the inner membrane of $E$. coli.

Briefly, The mid-log phase of $E$. coli were separately centrifuged (8000rpm, $5 \mathrm{~min}$ ), washed and resuspended in a 1:1 ratio of $5 \mathrm{mM}$ glucose and HEPES buffer ( $\mathrm{pH}=7.4$ ). The working concentration of $E$. coli was $1 \times 10^{8} \mathrm{CFU} / \mathrm{mL}$. After that, $190 \mu \mathrm{L}$ of bacterial suspension containing $10 \mu \mathrm{M}$ propidium iodide (PI) was added to the well of a black Corning 96-well plate with a clear bottom. Next, $10 \mu \mathrm{L}$ of MPX (1 MIC, 2 MIC, 4 MIC) was added to the wells containing dye and bacterial suspension. The control was $\mathrm{ddH}_{2} \mathrm{O}$. An excitation wavelength of $535 \mathrm{~nm}$ and emission wavelength of $617 \mathrm{~nm}$ were used to monitor the PI fluorescence for 10 min using an INFINITE M PLEX microplate reader (Ghosh C. et al., 2016).

Detection of MPX to inhibit $E$. coli from forming biofilms.
The ability of MPX inhibited $E$. coli biofilm formation was tested according to the reference (Grasteau A. et al., 2011) In a 96-well polystyrene microtiter plate, the overnight cultured $E$. coli was inoculated into $100 \mathrm{uL}$ of LB liquid medium according to the amount of $1 \%$, and different concentrations of MPX $(0.5 \mathrm{MIC}, 1$ MIC, 2 MIC, $4 \mathrm{MIC}) ; \mathrm{ddH}_{2} \mathrm{O}$ is used as a negative control. Place the culture plate in a $37^{\circ} \mathrm{C}$ incubator for $24 \mathrm{~h}$. Aspirated and discarded the culture supernatant. Washed each well with $200 \mathrm{uL}$ sterile PBS 3 times; fixed with $70 \%$ methanol for 30 min; aspirated and discarded the fixative at $37^{\circ} \mathrm{C}$ dry in the incubator for $30 \mathrm{~min}$; added $100 \mathrm{uL}$ of $1 \%$ Hucker crystal violet staining solution to each well, and stained for $5 \mathrm{~min}$ at room temperature; removed the staining solution, and rinsed the culture plate under a slow stream of water until the flowing water was colorless; After the oven was dried, placed it under a microscope for observation; then added $100 \mathrm{uL}$ of $70 \%$ ethanol solution to each well for decolorization, vortex and mix, and quickly placed it in a multifunctional microplate reader to determine the absorbance value of OD 570 (Grasteau A. et al., 2011). biofilm

Scanning electron microscope observed the formation of

After culturing the $E$. coli overnight, diluted it with fresh LB liquid medium by 100 times, transfer it to a 6 -well cell plate with sterile glass slides, add $500 \mathrm{uL}$ bacterial solution to each well, added MPX (1 MIC), ddH $\mathrm{H}_{2} \mathrm{O}$ as negative control. After $24 \mathrm{~h}$ of incubation in a constant temperature incubator at $37^{\circ} \mathrm{C}$, slowly removed the cell culture solution and rinsed with sterile saline for 3 times to wash away floating bacteria. Add $300 \mathrm{uL}$ of $2.5 \%$ glutaraldehyde solution to each well. After fixation at room temperature for $30 \mathrm{~min}$, rinsed with $\mathrm{pH}=7.4$ phosphate buffer for 3 times, with an interval of 10 min each time. 30\%, 50\%,70\%, 80\%, 90\%, $95 \%, 100 \%$ alcohol gradient dehydration respectively, each time interval of $15 \mathrm{~min}$. After the slides are dry, observe the formation of biofilm under scanning electron microscope (Wang L. et al., 2020).

\section{Statistical analyses.}

GraphPad Prism 8.0 software to perform data statistics and difference analysis of experimental results (One-Way ANOVA or Two-Way ANOVA). $P \leq 0.05$ is considered as significant difference ( ${ }^{*} P<0.05$; ${ }^{* *} P<0.01$; $\left.{ }^{* *} P<0.001\right)$.

\section{Results.}

MPX bactericidal activity detection results.

The antibacterial activity of MPX against $E$. coli was detected by double-layer agarose amplification. It was found that MPX could effectively inhibit the growth of $E$. coli at $1 \mathrm{mg} / \mathrm{mL}$, and the size of the antibacterial ring was equivalent to that of Enro $(1 \mathrm{mg} / \mathrm{mL})$. The negative control has no antibacterial activity. In addition, a modified micro broth dilution method was used to determine the minimum inhibitory concentration of MPX against $E$. coli $31.25 \mathrm{ug} / \mathrm{mL}$. In order to test the bactericidal activity of the antimicrobial peptide MPX against $E$. coli, the $\mathrm{OD}_{600}$ value of the bacterial culture was measured, and it was found that the $\mathrm{OD}_{600}$ of the bacterial culture solution decreased to 0.1 after the antimicrobial peptide MPX acted on for $6 \mathrm{~h}$, which was significantly lower than that of the control group (Figure $1 \mathrm{~A}, p<0.01)$ ). The bactericidal activity of MPX against $E$. coli was measured by a plate counting method. It was found that MPX showed an MICdependent increase in the bactericidal efficiency of $E$. coli. The number of bacteria was significantly reduced (Figure 1B). 

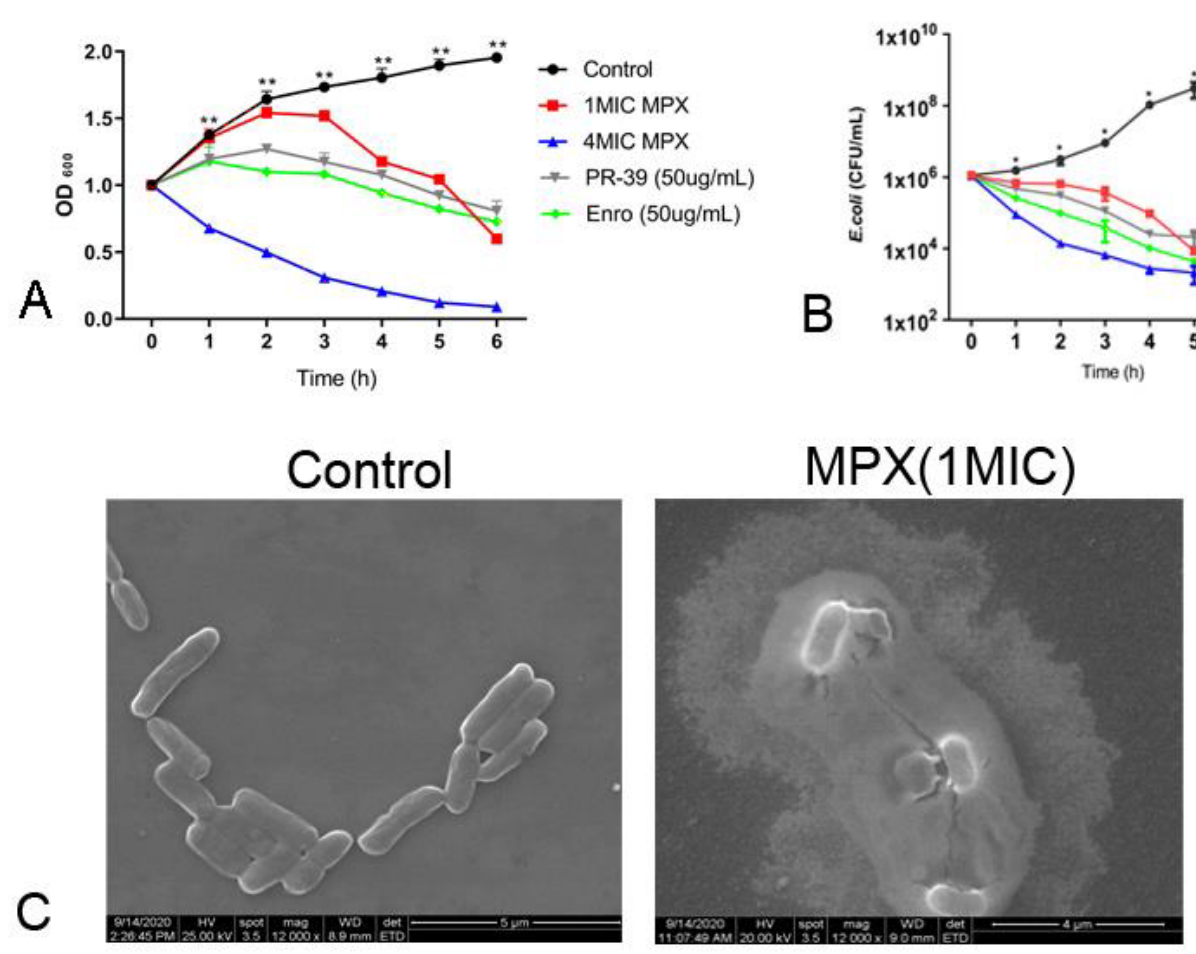

Fig. 1 The bactericidal activity detection of MPX in vitro.

A. The E.coli $\mathrm{OD}_{600}$ detection after treatment with MPX;

B. The E.coli plate count detection after treatment with MPX;

C. The effect of MPX on E. coli was detected by scanning electron microscope.

Scanning electron microscope was used to observe the effect of MPX on the morphology of $E$. coli. The results showed that the negative control $E$. coli has a full morphology, large cells, and a smooth surface. After MPX (1 MIC) treatment for $2 \mathrm{~h}$, the cells became significantly smaller, resulting in leakage of bacterial contents (Figure $1 \mathrm{C}$ ). The above results all indicate that MPX can effectively kill $E$. coli in vitro. tivity of MPX.

The effect of $\mathrm{pH}$ and temperature on the antibacterial ac-

In order to study the effect of $\mathrm{pH}$ and temperature on the antibacterial activity of MPX, the antibacterial radius method was used to determine the antibacterial activity of MPX on E. coli at different $\mathrm{pH}$ values and temperatures. As shown in Figure $2 \mathrm{~A}$, the $\mathrm{pH}$ in the range of 2-9 has no effect on MPX activity. When $\mathrm{pH}>10$, the antibacterial activity of MPX decreases, indicating that the activity of MPX was stable compared in acidic and weakly alkaline environments. The MPX was subjected to different temperature treatments, and the highest temperature reached $100^{\circ} \mathrm{C}$. It was found that the temperature had no effect on the antibacterial activity of MPX, indicating that MPX has good thermal stability (Figure 2B).
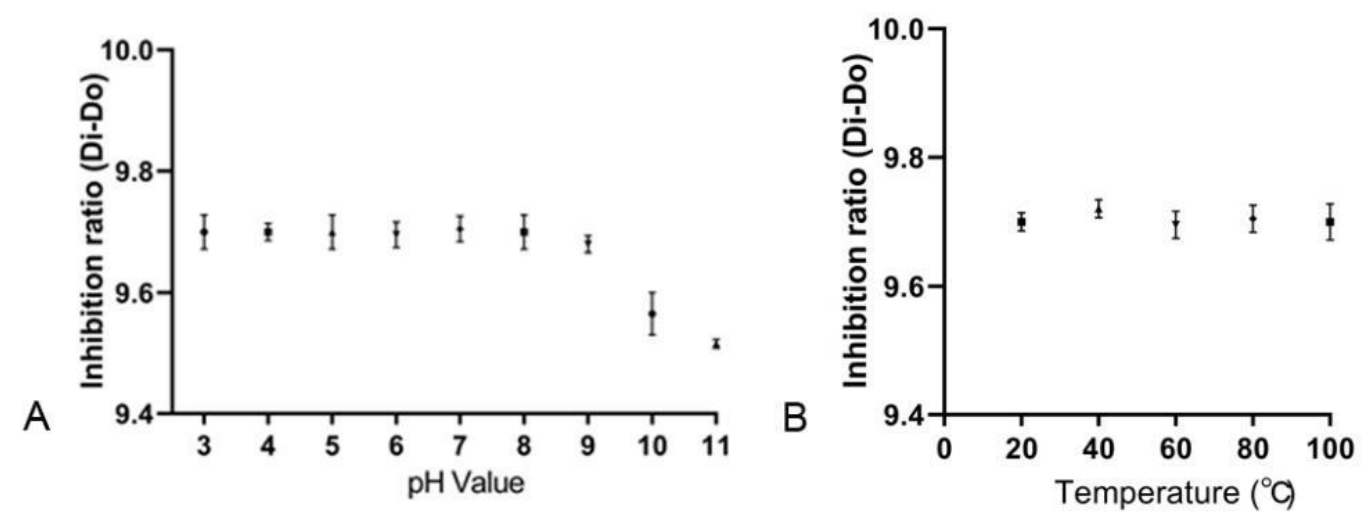

Fig. 2 The effect of $\mathrm{pH}$ and temperature on MPX.

A. The effect of pH on MPX; $B$. The effect of temperature on MPX.

The effect of ions on the antibacterial activity of MPX.

In order to study the effect of different salt ions on the activity of MPX after treating with MPX at different concentrations of cations $\mathrm{Na}^{+}, \mathrm{K}^{+}, \mathrm{Mg}^{2+}, \mathrm{Ca}^{2+}$, it was found that cations $\mathrm{Na}^{+}, \mathrm{K}^{+}$ had no effect on the antibacterial activity of MPX, while cationic
$\mathrm{Mg}^{2+}$ and $\mathrm{Ca}^{2+}$ had effect on MPX activity (Figure $3 \mathrm{~A}-\mathrm{D}$ ). It is speculated that the presence of cationic $\mathrm{Ca}^{2+}$ leads to changes in the secondary structure of MPX, thereby affecting its antibacterial activity. 

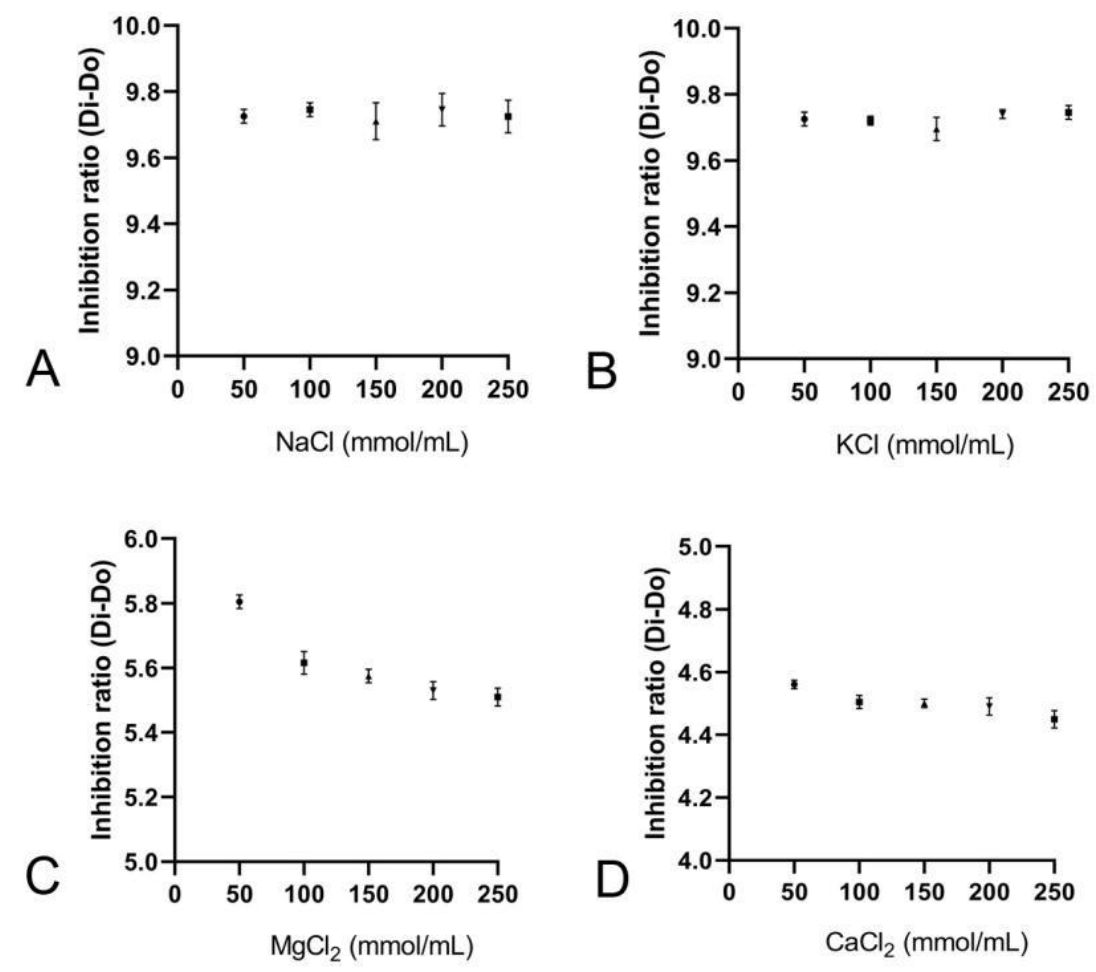

Fig. 3 The effect of cations $\mathrm{Na}^{+}, \mathrm{K}^{+}, \mathrm{Mg}^{2+}, \mathrm{Ca}^{2+}$ on the activity of MPX

A. The effect of cations $\mathrm{Na}^{+}$on the activity of MPX; B. The effect of cations $\mathrm{K}^{+}$on the activity of MPX; C. The effect of cations $\mathrm{Mg}^{2+}$ on the activity of MPX; D. The effect of cations $\mathrm{Ca}^{2+}$ on the activity of MPX.

Bacterial permeability of MPX.

In order to study the permeability of antimicrobial peptide MPX to E. coli strains, BCA protein content determination and immunofluorescence observation was used in this study and found that the protein content in supernatant of E.coli was significantly higher than that of the control group after the action of MPX treatment for 3 hours (Figure 4A), The protein content is significantly higher than MPX (1 MIC) after treatment with MPX (2 MIC), and the effect of MPX on E. coli is positively correlated with the concentration. Fluorescence microscope used SYTO 9/PI (Properly mix SYTO 9 and PI staining, bacteria with intact cell membranes are stained fluorescent green, while bacteria with damaged cell membranes are stained fluorescent red). Compared with the control group, the integrity of the cell membrane was damaged after MPX (2 MIC) treatment, PI entered into the bacterial cells, and the number of dead bacteria increased significantly. The effect was significantly better than that of MPX 1MIC, and it was consistent with the BCA protein content determination results. MPX exerts its bactericidal function by changing the permeability of bacteria.

The permeability of MPX to the outer membrane of $E$. coli was measured by NPN uptake assay. NPN is a neutral hydrophobic fluorescent probe, which is usually excluded by the outer membrane, but the fluorescence intensity increases when it enters the outer membrane. As shown in Figure 4C, MPX rapidly penetrated the outer membrane of $E$. coli in a concentration-dependent manner, which could be observed by the increase in NPN fluorescence. MPX could penetrate the outer membrane of E. coli even at a concentration of $1 \mathrm{MIC}$ in a dose-dependent manner.

PI was used to determine the permeability of MPX to the inner membrane of $E$. coli. Due to its strong binding to bacterial DNA, the fluorescence of $\mathrm{PI}$ increases when it enters the damaged bacterial cell. After E. coli treatment with MPX, the PI fluorescence intensity was significantly increased, and the fluorescence signal intensity increased in a concentration-dependent manner (Figure 4D). 

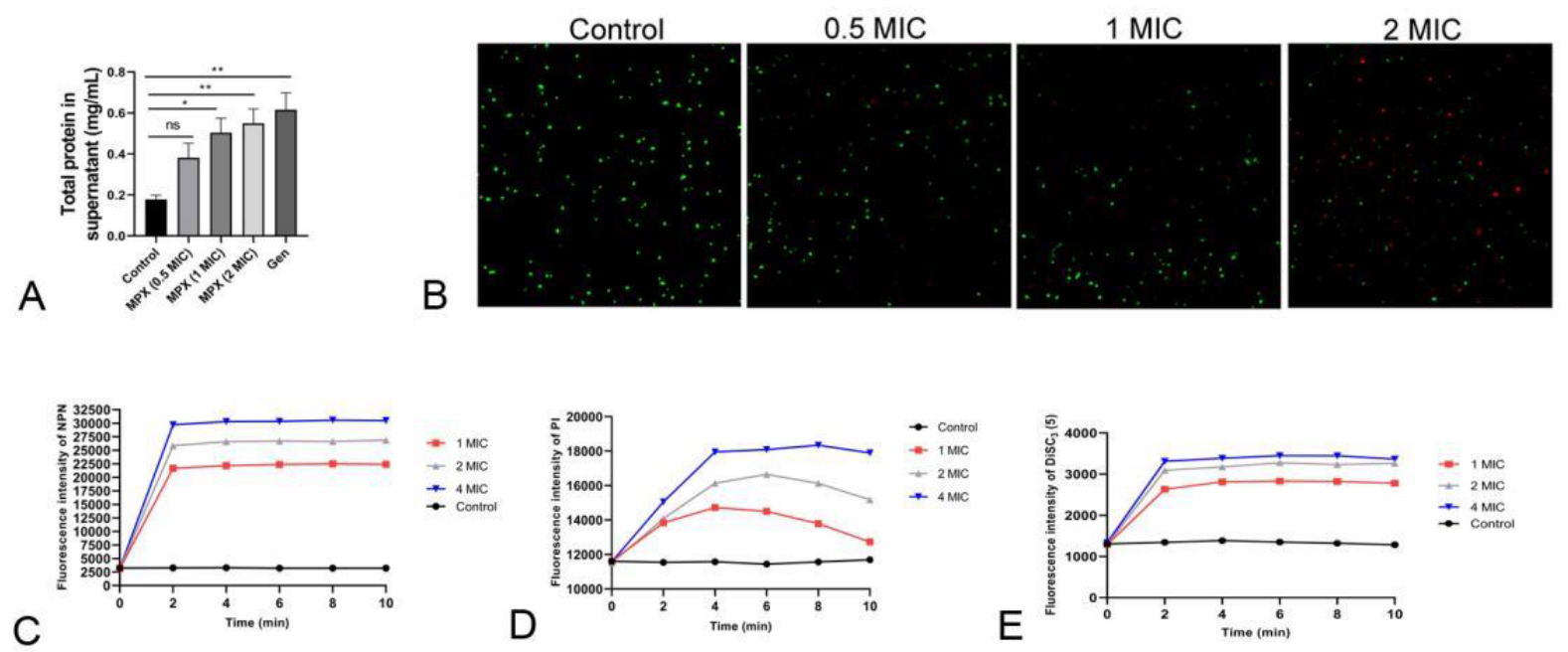

Fig. 4 The effect of MPX on the permeability of E. coli.

A. The results of total protein in E.coli bacterial supernatant after MPX treatment;

B. The effect of MPX on the permeability of $E$. coli was observed by immunofluorescence;

C. Detection of NPN fluorescence after MPX treatment with E. coli;

D. Detection PI of fluorescence after MPX treatment with $E$. coli;

E. Detection of DISC3(5) fluorescence after MPX treatment with $E$. coli.

The effect of MPX on the depolarization of E. coli cytoplasmic membrane was observed. Membrane-potential sensitive dye 3,3'-dipropylthiadicarbocyanine iodide [DiSC3(5)] was used for this study. Under the normal potential on the cell membrane, DiSC3 (5) dye is distributed inside and outside the bacterial cell. Therefore, the initial fluorescence intensity of the dye decreases due to its "self-quenching" within the bacterial cell. After treatment with drugs that affect the normal membrane potential, the release of the dye in the external medium increases, which in turn leads to an increase in fluorescence intensity. After adding different concentrations of MPX (1MIC, 2 MIC, $4 \mathrm{MIC}$ ), it was found that the fluorescence intensity of $E$. coli increased with the increase of the concentration of MPX (Figure 4E). This result showed that MPX had a significant effect on the normal membrane potential of $E$. coli.

The effect of MPX on $E$. coli biofilm formation.

The formation of $E$. coli biofilm plays an important role in its virulence and drug resistance. Therefore, this study first adopted the crystal violet method to study the effect of MPX on the biofilm formation of $E$. coli. The results showed that compared with the control group, MPX (1 MIC) could reduce the formation of $\mathrm{E}$. coli biofilm in a dose-dependent manner, and MPX (4 MIC) had the best effect (Figure 5A). Furthermore, after using 70\% alcohol to dissolve the crystal violet, the absorbance value was measured with an $\mathrm{OD}_{570}$ spectrophotometer, compared with the control group, MPX significantly reduced the absorbance value of the $E$. coli biofilm (Figure $5 \mathrm{~B}$ ).

Scanning electron microscope was used to observe the effect of MPX (1 MIC) on the biofilm of $E$. coli, which resulted in a loose structure, reduced bacterial adhesion, and an increase in the gap between bacteria. While control group formed dense biofilm with small gaps between bacteria (Figure 5). The above results indicate that MPX can significantly inhibit the formation of $E$. coli biofilm.
A
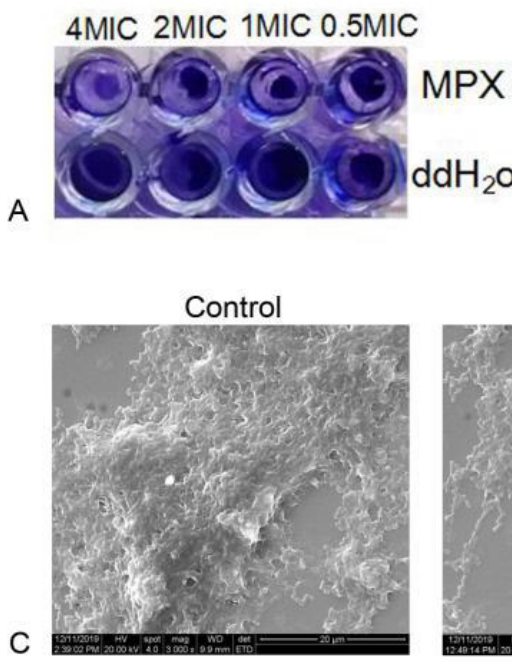

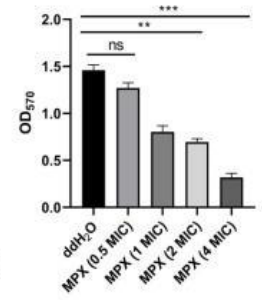

B

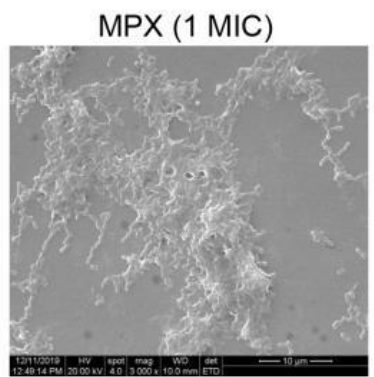

Fig. 5 The effect of MPX on the formation of E.coli biofilm.

A. The effect of MPX on E. coli biofilm by crystal violet staining; B. OD 570 detected the effect of MPX on $E$. coli biofilm; C. The effect of MPX on the biofilm formation of $E$. coli by scanning electron microscope. 


\section{Discussion and Conclusion}

In recent years, the unreasonable use of antibiotics has led to an increase in the resistance of $E$. coli. Therefore, there is an urgent need to find alternatives to antibiotics. Amphaiphan $C$ and others isolated $E$. coli from dogs and cats suffering from urinary system diseases, and tested for drug sensitivity, and found that the resistance of $E$. coli was $16.7 \%$ (Amphaiphan C. et al., 2021) Fayemi OEFrom et al from 180 samples of fresh beef and meat products detected that 61 samples contained different serotypes of E. coli.

The resistance analysis of the isolated E. coli 0157:H7 showed that $23.6 \%$ resistance of STEC serotype (Fayemi O.E. et al., 2021) Sarjana Safain $K$ et al determined the spectrum of AMR and associated genes encoding aminoglycoside, macrolide and $\beta$-lactam classes of antimicrobials in bacteria isolated from hospitalized patients in Bangladesh, found that $53 \%$ of isolates were multidrug-resistant (MDR), including $97 \%$ of $E$. coli (Sarjana S.K. et al., 2021).

Shin $\mathrm{H}$ et al isolated high level carbapenem and extensively drug resistant (XDR) strain N7 of E.coli, which produces a variant of New Delhi metallo- $\beta$-lactamase (NDM-5) from the influent of the Jungnang wastewater treatment plant located on Han River, Seoul, South Korea N7, which harbors the gene, showed high level of carbapenem resistance at concentrations of doripenem $(512 \mathrm{mg} / \mathrm{L})$ and meropenem (256 mg/L), and XDR to 15 antibiotics (Shin $\mathrm{H}$. et al., 2021).

The above results indicate that $E$. coli has high resistant to antibiotics, and there is an urgent need to find the best alternative to antibiotics against $E$. coli infection. This study found that MPX has good antibacterial activity against $E$. coli, with a minimum inhibitory concentration of $31.25 \mathrm{ug} / \mathrm{mL}$ and has no drug resistance, indicating that MPX is expected to become one of the antibiotic alternatives for the treatment of $E$. coli infections.

The formation of bacteria biofilm leads to an increase in bacterial resistance. Morroni $\mathrm{G}$ et al. found that the antimicrobial peptide LL-37 has good antibacterial activity against multi-drug resistant $E$. coli, and MIC and sub-MIC concentrations of LL-37 were able to reduce $E$. coli biofilm formation (Morroni G. et al., 2021) Vergis $J$ et al found that the antimicrobial peptide Lactoferricin (17-30) has good antibacterial and anti-biofilm activity against multi-drug-resistant Enteroaggregative Escherichia coli, and Lactoferricin (17-30) significantly reduced the formation of $E$. coli biofilm (Vergis J. et al., 2020) Mishra BE et al found that antimicrobial peptide WW298 could effectively inhibit the MRSA attachment and disrupt its preformed biofilms more effectively than daptomycin (Mishra B. et al., 2020). Liu Ye et al found that tryptophan-rich amphiphilic peptide termed WRK-12 significantly inhibited the formation of biofilm in a dose-dependent manner, especially multidrug-resistant (MDR) bacteria particularly Gramnegative bacteria (Liu Y. et al., 2020) This study found that MPX (1 MIC) significantly inhibited the formation of $E$. coli biofilm, indicating that antibacterial peptides have a good antibacterial biofilm formation effect, which lays the foundation for the development of antibacterial biofilm formation drugs.

In summary, the above results show that MPX has a good killing effect on $E$. coli and the stability was less affected by temperature, $\mathrm{pH}$, and ions. In addition, MPX could significantly inhibit the formation of $E$. coli biofilms. This research provides a theoretical basis for the development of new drugs against $E$. coli infection.

\section{Author's contributions}

All authors participated in this article design. Xueqin Zhao participated and performed writing and data collection. All authors have read and approved the final manuscript for publication.

\section{Acknowledgments}

This work was supported by the National Natural Science Foundation of China (No. 31702259 and 31520103917), Young Talent Lifting Project in Henan Province (2020HYTP041), Key Scientific Research Projects of Colleges and University in Henan Province (21A230004).

Conflict of interest Author does not report any financial or personal connections with other persons or organizations, which might negatively affect the contents of this publication and/or claim authorship rights to this publication.

\section{References:}

1. Amphaiphan C, Yano T, Som-In M, et al. (2021). Antimicrobial drug resistance profile of isolated bacteria in dogs and cats with urologic problems at Chiang Mai University Veterinary Teaching Hospital, Thailand (2012-2016). Zoonoses Public Health. doi:10.1111/zph.12832.

2. Andrejko M, Mak P, Sieminska-Kuczer A, et al. (2021). A comparison of the production of antimicrobial peptides and proteins by Galleria mellonella larvae in response to infection with two Pseudomonas aeruginosa strains differing in the profile of secreted proteases. J Insect Physiol. 104239, doi:10.1016/j.jinsphys.2021.104239.

3. Fayemi O E, Akanni G B, Elegbeleye J A, Aboaba O O, Njage P M. (2021). Prevalence, characterization and antibiotic resistance of Shiga toxigenic Escherichia coli serogroups isolated from fresh beef and locally processed ready-to-eat meat products in Lagos, Nigeria. Int J Food Microbiol. 347, 109191, doi:10.1016/j.ijfoodmicro.2021.109191.

4. Fleckenstein J M, Hardwidge P R, Munson G P, Rasko D A, Sommerfelt H, Steinsland H. (2010). Molecular mechanisms of enterotoxigenic Escherichia coli infection. Microbes Infect. 12, 89-98, doi:10.1016/j.micinf.2009.10.002.

5. Ghosh C, Manjunath G B, Konai M M, et al. (2016). Aryl-alkyl-lysines: Membrane-Active Small Molecules Active against Murine Model of Burn Infection. ACS Infect Dis. 2, 111-22, doi:10.1021/acsinfecdis.5b00092.

6. Grasteau A, Tremblay Y D, Labrie J, Jacques M. (2011). Novel genes associated with biofilm formation of Actinobacillus pleuropneumoniae. Vet Microbiol. 153, 134-43, doi:10.1016/j.vetmic.2011.03.029.

7. Henriksen J R, Etzerodt T, Gjetting T, Andresen T L. (2014). Side chain hydrophobicity modulates therapeutic activity and membrane selectivity of antimicrobial peptide mastoparan-X. PLOS One. 9, e91007, doi:10.1371/journal.pone.0091007.

8. Konai M M, Ghosh C, Yarlagadda V, Samaddar S, Haldar J. (2014). Membrane active phenylalanine conjugated lipophilic norspermidine derivatives with selective antibacterial activity. J Med Chem. 57, 9409-23, doi:10.1021/jm5013566.

9. Liu Y, Shi J, Tong Z, Jia Y, Yang K, Wang Z. (2020). Potent Broad-Spectrum Antibacterial Activity of Amphiphilic Peptides against Multidrug-Resistant Bacteria. Microorganisms. 8, doi:10.3390/microorganisms8091398.

10. Luu T, Li W, O'Brien-Simpson N M, Hong Y. (2021). Recent Applications of Aggregation Induced Emission Probes for Antimicrobial Peptide Studies. Chem Asian J. doi:10.1002/asia.202100102. 
11. Madhavan T P, Sakellaris H. (2015). Colonization factors of enterotoxigenic Escherichia coli. Adv Appl Microbiol. 90, 15597, doi:10.1016/bs.aambs.2014.09.003.

12. Mishra B, Lakshmaiah N J, Lushnikova T, Zhang Y, Golla R M, Zarena D, Wang G. (2020). Sequence Permutation Generates Peptides with Different Antimicrobial and Antibiofilm Activities. Pharmaceuticals (Basel). 13, doi:10.3390/ph13100271.

13. Morroni G, Sante L D, Simonetti O, et al. (2021). Synergistic effect of antimicrobial peptide LL-37 and colistin combination against multidrug-resistant Escherichia coli isolates. Future Microbiol. 16, 221-227, doi:10.2217/fmb-2020-0204.

14. Sarjana S K, Sarower B G, Hassan H S, et al. (2021). Genotypic and phenotypic profiles of antibiotic-resistant bacteria isolated from hospitalized patients in Bangladesh. Trop Med Int Health. doi:10.1111/tmi.13584.

15. Shin H, Kim Y, Han D, Hur H G. (2021). Emergence of High Level Carbapenem and Extensively Drug Resistant Escherichia coli ST746 Producing NDM-5 in Influent of Wastewater Treatment Plant, Seoul, South Korea. Front Microbiol. 12, 645411, doi:10.3389/fmicb.2021.645411.

16. Song X, Yang Y, Li J, et al. (2021). Tannins extract from Galla Chinensis can protect mice from infection by Enterotoxigenic Escherichia coli 0101. BMC Complement Med Ther. 21, 84, doi:10.1186/s12906-021-03261-x.

17. Uppu D S, Akkapeddi P, Manjunath G B, Yarlagadda V, Hoque J, Haldar J. (2013). Polymers with tunable side-chain amphiphilicity as non-hemolytic antibacterial agents. Chem Commun (Camb). 49, 9389-91, doi:10.1039/c3cc43751e.

18. Van Boeckel T P, Pires J, Silvester R, et al. (2019). Global trends in antimicrobial resistance in animals in low- and middleincome countries. Science. 365, doi:10.1126/science.aaw1944.

19. Vergis J, Malik S S, Pathak R, et al. (2020). Exploiting Lactoferricin (17-30) as a Potential Antimicrobial and Antibiofilm Candidate Against Multi-Drug-Resistant Enteroaggregative Escherichia coli. Front Microbiol. 11, 575917, doi:10.3389/fmicb.2020.575917.

20. Wang L, Zhao X, Zhu C, et al. (2017). Thymol kills bacteria, reduces biofilm formation, and protects mice against a fatal infection of Actinobacillus pleuropneumoniae strain L20. Vet Microbiol. 203, 202-210, doi:10.1016/j.vetmic.2017.02.021.

21. Wang L, Zhao X, Zhu C, et al. (2020). The antimicrobial peptide MPX kills Actinobacillus pleuropneumoniae and reduces its pathogenicity in mice. Vet Microbiol. 243, 108634, doi:10.1016/j.vetmic.2020.108634.

Ксюєцінь Дзяо, аспірант каффедри ветеринарної експертизи, мікробіології, зоогігієни та безпеки та якості продукиії тваринництва Сумського НАУ

Ганна Фотіна, доктор ветеринарних наук, просресор

Лей ВАНГ, коледж наук про тварин і ветеринарної медицини, Інститут науки і техніки Хенань, (Сіньсян, Китай)

Ху Цзяньхе, профессор, Коледж наук про тварин іветеринарної медицини, Інститут науки і техніки Хенань (Китай)

Механізм дії антимікробного пептиду MPX проти ентерогеморрагічної Escherichia coli in vitro

Метою нашої роботи було дослідженні механізму протимікробного пептиду MPX проти кишкової палички in vitro. Дослідження проводили в лабораторії безпеки та якості продуктів тваринниитва Сумського НАУ, факультету ветеринарної медицини, Суми, Україна та на базі Науково-технічного інституту Хенань, Сіньсян, Китай. Кишкова паличка - факультативна анаеробна бактерія, яка в основному існує в шлунково-кишковому тракті людей і тварин, колонізується в тонкому кишечнику, що зазвичай пов'язано з гострою секреторною діареєю. Це може спричинити діарею, ентерит, руйнування кишкового бар'єру господаря та кишкові мікроекологічні порушення. В останні роки через зловживання традиційними антибіотиками безліч резистентних штамів та супер бактерій з'явилися у незліченній кількості. Тому існує нагальна потреба у пошуку нових альтернатив антибіотикам. Антимікробні пептиди - це тип малих пептидів, що утворюються, коли організми протистоять вторгненню чужорідних мікроорганізмів. Вони вважаються найкращою альтернативою антибіотикам, яка за останні роки стала точкою досліджень. Антимікробний пептид MPX витягується з отрути оси і має хороший бактерицидний ефект відносно багатьох бактерій. Було джосліджено вплив MPX проти кишкової палички. Функцію MPX проти кишкової палички визначали за допомогою MIC, кількості пластин, йодиду пропідію, тесту проникності NPN ma DiSC3 (5), спостереження з використанням імунофрлуоресцентного мікроскопу та впливу стабільності MPX за температури, pH, іона. У цьому дослідженні виявили, що МPX має хорошу антибактеріальну активність щодо кишкової палички, а мінімальна інгібуюча концентрація (MIC) становила 31,25 мка / мл. Дослідження бактерицидної кінетики MPX показало, що МPX мав хорошу бактерицидну активність протягом 6 годин. Дослідження проникності бактерій показали, що MPX може збільшити проникність бактерій, що призведе до збільшення вмісту білка в супернатанті бактерій. Крім того, результати NPN, PI ma DiSC3 (5) показали, що значення фллуоресценції позитивно корелювало з MPX. Teст на стійкість МРХ виявив, що іони солі, температура, рН тощо мають незначний вплив на його вплив. Крім того, результати скануючої електронної мікроскопії показали, що бактерій стало менше, а вміст витік після дії МРX. Наведені вище результати показали, що MPX має хорошу бактерицидну активність in vitro, закладаючи основу для розробки нових препаратів для лікування бактеріальних інфекицій.

Ключові слова: MPX, бактерицидна активність, антимікробні пептиди, резистентні штами 